\title{
Simultaneous tracking of blue whales and large ships demonstrates limited behavioral responses for avoiding collision
}

\author{
Megan F. McKenna ${ }^{1,2,5, *}$, John Calambokidis ${ }^{2}$, Erin M. Oleson ${ }^{3}$, David W. Laist ${ }^{1}$, \\ Jeremy A. Goldbogen ${ }^{4}$ \\ ${ }^{1}$ Marine Mammal Commission, 4340 East-West Highway, Suite 700, Bethesda, MD 20814, USA \\ ${ }^{2}$ Cascadia Research Collective, $218^{1 / 2}$ West 4th Ave., Olympia, WA 98501, USA \\ ${ }^{3}$ NOAA-NMFS-Pacific Islands Fisheries Science Center, 1601 Kapiolani Blvd. Ste. 1110, Honolulu, HI 96814, USA \\ ${ }^{4}$ Department of Biology, Hopkins Marine Station, Stanford University, Pacific Grove, CA 93950, USA \\ ${ }^{5}$ Present address: National Park Service, 1201 Oakridge Drive, Fort Collins, CO 80525, USA
}

\begin{abstract}
Collisions between ships and whales are reported throughout the world's oceans. For some endangered whale populations, ship strikes are a major threat to survival and recovery. Factors known to affect the incidence and severity of collisions include spatial co-occurrence of ships and whales, hydrodynamic forces around ships, and ship speed. Less understood and likely key to understanding differences in interactions between whales and ships is whale behavior in the presence of ships. In commercial shipping lanes off southern California, we simultaneously recorded blue whale behavior and commercial ship movement. A total of 20 ship passages with 9 individual whales were observed at distances ranging from 60 to $3600 \mathrm{~m}$. We documented a dive response (i.e. shallow dive during surface period) of blue whales in the path of oncoming ships in $55 \%$ of the ship passages, but found no evidence for lateral avoidance. Descent rate, duration, and maximum depth of the observed response dives were similar to whale behavior immediately after suction-cup tag deployments. These behavioral data were combined with ship hydrodynamic forces to evaluate the maximum ship speed that would allow a whale time to avoid an oncoming ship. Our analysis suggests that the ability of blue whales to avoid ships is limited to relatively slow descents, with no horizontal movements away from a ship. We posit that this constrained response repertoire would limit their ability to adjust their response behavior to different ship speeds. This is likely a factor in making blue whales, and perhaps other large whales, more vulnerable to ship strikes.
\end{abstract}

KEY WORDS: Ship-whale collision · Blue whales · Avoidance behavior · Ship speed · AIS · Bio-logging tags

\section{INTRODUCTION}

Collisions between ships and whales are reported regularly throughout the world's oceans and for some species of endangered whales, ship strikes are a major threat to their survival and recovery (Clapham

\footnotetext{
*Corresponding author: megan_f_mckenna@nps.gov
}

et al. 1999, Laist et al. 2001, Douglas et al. 2008, Berman-Kowalewski et al. 2010, Neilson et al. 2012), though some recent work has questioned the degree of risk they pose at a population level (Monnahan et al. 2014). Often these collisions result in serious injury or death; however, it is highly likely that only a

() The authors 2015. Open Access under Creative Commons by Attribution Licence. Use, distribution and reproduction are unrestricted. Authors and original publication must be credited. 
small fraction of struck carcasses are recovered, and reported numbers are most likely underestimates (Williams et al. 2011). Understanding interactions between ships and large whales has become a global conservation issue owing to increases in commercial shipping traffic and predicted growth of the industry (Corbett \& Winebrake 2007). A number of mitigation efforts have been initiated to reduce these impacts (Silber et al. 2012). To date they have focused on reducing spatial overlap between ships through routing measures (Van der Hoop et al. 2012, Redfern et al. 2013) or reducing ship speeds in sensitive whale habitat (Gende et al. 2011, Lagueux et al. 2011, McKenna et al. 2012, Silber \& Bettridge 2012).

The incidence and severity of ship-whale collisions has been linked to a number of factors. Analyses of documented ship-whale collisions suggest that ship speed may be one of the factors. The probability of lethality becomes less common at speeds below 7.2 to $7.7 \mathrm{~m} \mathrm{~s}^{-1}$ (14 to 15 knots) and rare at speeds below $5.1 \mathrm{~m} \mathrm{~s}^{-1}$ (10 knots) (Laist et al. 2001, Vanderlaan \& Taggart 2007, Wiley et al. 2011). Explanations of the increased lethality at higher speeds include greater impact forces with increasing ship speeds (Campbell-Malone \& Barco 2008), an increase in acceleration forces as ship speeds increase (Silber et al. 2010), and whale avoidance (Laist et al. 2001). An analysis of lethal injuries from ships under different speed regulations found that ship speed limits can be an effective tool for reducing mortality risk for certain species of whales (Conn \& Silber 2013), particularly for right whales Eubalaena glacialis in and near areas of restricted speed along the United States east coast (Laist et al. 2014). In an analysis of large-whale mortalities along the entire east coast of North America, Van der Hoop (2013) reported no overall change in ship-strike mortalities after multiple mitigation efforts, but results are only applicable on the larger spatial scale and localized efforts appear to have been successful (Laist et al. 2014). Given that the relationship between lethality and ship speed depended on reports of known ship-whale collisions, it remains unclear if the results are biased by a lower detection of collisions when ships are traveling at slower speeds $\left(<7.2 \mathrm{~m} \mathrm{~s}^{-1}[<14 \mathrm{knots}]\right)$.

Few studies have examined how whales react to closely approaching large ships, yet this is likely a key to understanding the differing vulnerability of species, the reduced incidence of ship-strike at slower speeds, and the effectiveness of mitigation. Possible avoidance responses may include vertical movements to avoid ships by diving beneath them or remaining at depth until ships pass, or horizontal movements and changes in swim speed to avoid oncoming ships. An approaching ship may elicit a threat-like response, which may include longer surface intervals, increased breath rate, or shallower diving. It is also possible that whales do not change their behavior in the presence of ships. Evidence in support of any behavioral response of whales has been limited by logistical challenges of gathering high-resolution whale behavioral data in the presence of large ships. Anecdotal information from whalers suggests whales are less responsive while feeding and response may be related to feeding technique, specifically surface feeding would increase vulnerability (Laist et al. 2001). To date, the only support for a 'startle response' consists of anecdotal reports of whales taking evasive action within a few hundred meters of oncoming ships (Laist et al. 2001). Bio-logging tag data from whales occupying areas of high shipping traffic, however, can provide detailed whale behavior during close encounters with ships. This technique has been used to examine manatee reactions to recreational boats and tourism vessels (Miksis-Olds et al. 2007, Ryck 2013).

In this study, we combined data from tagged blue whales Balaenoptera musculus with automatic identification system (AIS) ship-tracking data collected off the coast of southern California, a region of high shipping density (Redfern et al. 2013). The primary access route into one of the world's largest ports, the Port of Los Angeles-Long Beach (POLA) travels through this region. POLA is the second busiest port in North America (CINMS 2009). Until recently, an estimated $75 \%$ of the vessels leaving, and $65 \%$ of vessels arriving at, POLA and Port Hueneme traveled through the Santa Barbara Channel (SBC) (CINMS 2009). Commercial vessel traffic in the SBC is concentrated in designated shipping lanes, with an average of 18 ships transiting per day (McKenna et al. 2009). The majority of traffic is categorized as cargo ships (e.g. container ships, bulk carriers, and vehicle carriers), traveling at average speeds of $10 \mathrm{~m}$ $\mathrm{s}^{-1}$ (19 knots).

This region is also a primary feeding ground for the Endangered eastern North Pacific (ENP) blue whale (Calambokidis et al. 1990, 2000, 2007). Aggregations of ENP blue whales come to this region to feed on dense patches of krill (Calambokidis et al. 2000, 2007). Recent estimates of the abundance of this population of blue whales, using both linetransect and mark-recapture methods, showed no clear increase, despite decades of commercial whaling ending in 1971 (Barlow 1995, Calambokidis \& Barlow 2004, Calambokidis et al. 2009). ENP blue 
whale population estimates are around 2000 to 3000 animals (Calambokidis \& Barlow 2004). A recent study suggested that density dependence is likely the key reason for the observed lack of increase (Monnahan et al. 2014). The only known source of juvenile and adult mortality for ENP blue whales is fatal collisions between ships and whales (Carretta et al. 2012), although noise, chemical pollution, and fishery interactions likely also impact the population. Between 1998 and 2007, 21 blue whale deaths were reported along the California coast; 4 of those deaths occurred in the fall of 2007 in the SBC (Berman-Kowalewski et al. 2010). Because the SBC was identified as an area of high ship-strike risk for this species (Berman-Kowalewski et al. 2010), our study targeted this region to understand how blue whales behave in the path of oncoming ships to help inform management of ships in regions of high ship traffic density.

Fine-scale ENP blue whale behavior (i.e. dive pattern and lateral movement) during close encounters with ships transiting the shipping lane off southern California were analyzed to understand and characterize behavioral responses to approaching ships. Based on our findings, we offer a theoretical framework for evaluating the consequences of varying ship speeds to mitigate ship-whale collisions.

\section{MATERIALS AND METHODS}

Whale behavioral data were collected on archival suction-cup tags attached to blue whales. Three different tag types were deployed: 2 types of acoustic recording tags (Bioacoustic Probe and Acousonde: Greeneridge Sciences) and GPS Fastloc location tags (TDR10-F: Wildlife Computers). The Bioacoustic Probe records acoustic data and is equipped with 3 auxiliary sensors (pressure, temperature, and 2-axis acceleration sampling at $1 \mathrm{~s}$ intervals). The Acousonde, a more recent tag design, houses a 3-axis accelerometer and a higher frequency hydrophone, and has higher sampling rates $(10 \mathrm{kHz})$ for the auxiliary sensors. The TDR10-F tag records hydrostatic pressure at $1 \mathrm{~Hz}$, temperature, and GPS positions during whale surface periods.

Blue whales in or near shipping lanes off the coast of southern California (Fig. 1) were targeted for tag deployment. In some cases, after successful tag deployment, whales were tracked visually from a small boat. The tagged whale's position and ship passages were monitored by observers onboard the small research boat. In other cases, whales were tagged and not visually tracked; instead the TDR10F tag equipped with a Fastloc GPS collected whale GPS positions with a reported accuracy of 20 to $75 \mathrm{~m}$.

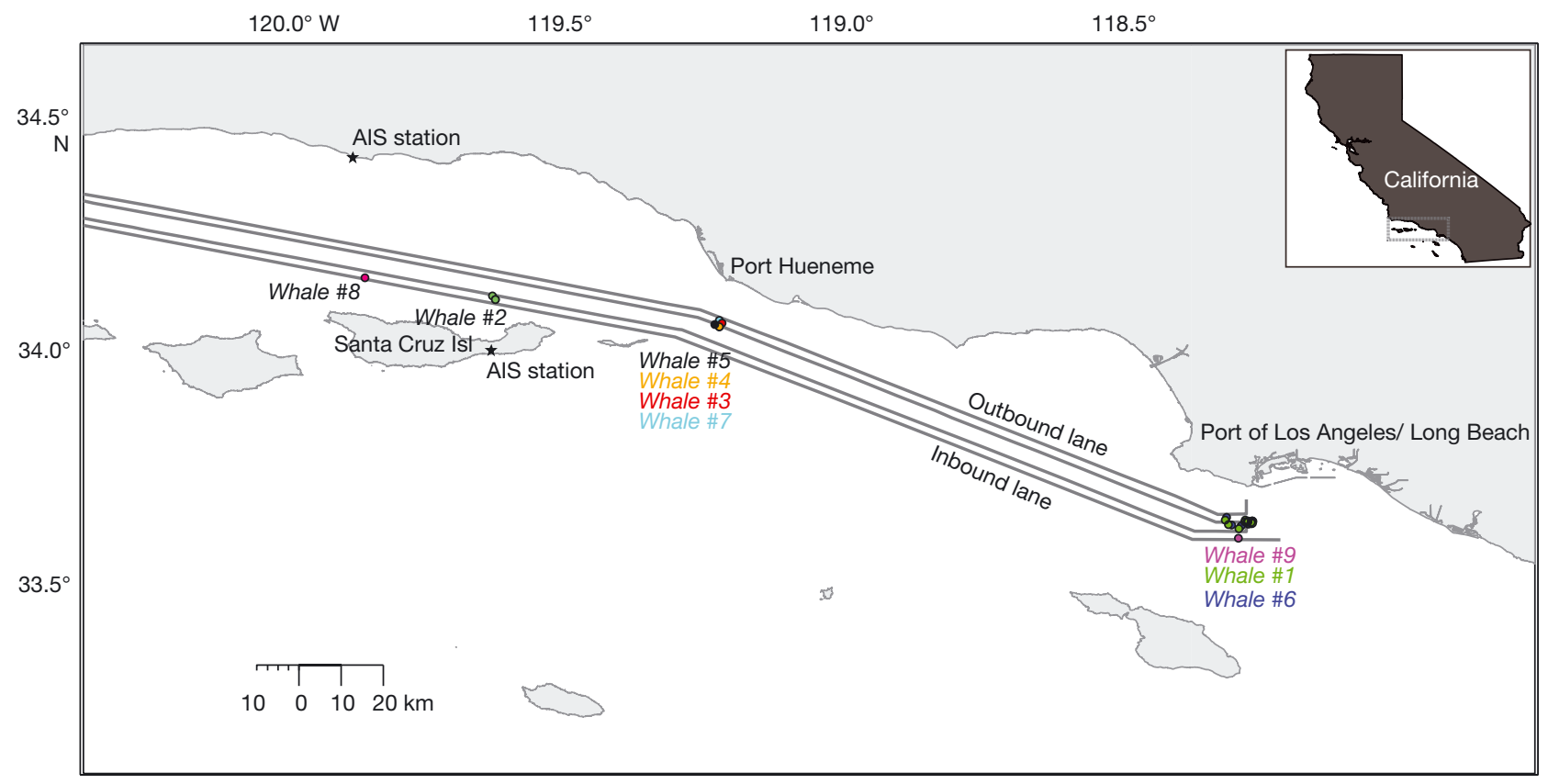

Fig. 1. Locations of documented ship passages to blue whales foraging off the coast of southern California. Whale numbering corresponds to Tables $1 \& 2$ and Figs. 2, 3, \& 5. Black lines indicate the commercial shipping traffic lanes through the Santa Barbara Channel into the ports of Los Angeles/Long Beach. $(\star)$ Locations of the automatic identification system (AIS) receivers used to collect the ship-track information 
Only high-quality GPS locations, defined as whale positions that were calculated from $>3$ satellite positions, were used. When the tags were recovered, the spatial data were combined with ship movement data from AIS to determine the time, location, and estimated minimum distance between the whales during ship passages.

AIS data were collected at multiple locations from all commercial ships $>300$ gross tons transiting the region. The shore-based AIS stations (Fig. 1) provided the entirety of the ship passages through the region, and the AIS receiver on the tagging boat provided real-time detail during ship passages. Large commercial ships are required to transmit information on their position, speed, and unique identification information via AIS (Tetreault 2005). AIS was developed to decrease the risk of ship collisions; therefore, the transmitted positional information is highly accurate. Ship AIS signals are transmitted every 6 to $10 \mathrm{~s}$, and, if some positions were not received at the shore stations due to atmospheric interference, ship tracks were interpolated to $10 \mathrm{~s}$ increments using the speed of the ship and the bounding positions. Whale posi- tional data were also interpolated to $10 \mathrm{~s}$ increments, assuming straight-line travel between positions and constant swim speed. The $10 \mathrm{~s}$ increments provided the necessary resolution to identify the distance and time of ship passages because a ship would not travel its length within in this time frame.

To define the closest point of approach (CPA) between the tagged whales and passing ships, the interpolated whale positional data were combined with the interpolated ship-track AIS data. First, the whale and ship positions closest in time were identified, and then the horizontal distance between the whale and ship was calculated based on these positions. This was defined as the CPA distance. The methodology of combining TDR10-F tag data with AIS data was verified through a comparison with known ship and whale positions (Fig. 2). Custom-built functions in MATLAB (Mathworks, Version 2012b) were developed to analyze and combine the whale-track and ship-track data. We defined a close approach as a ship passage within $1 \mathrm{~km}$ of a whale. This is an arbitrary distance thought to be a possible distance at which whales might be expected to react to ships by

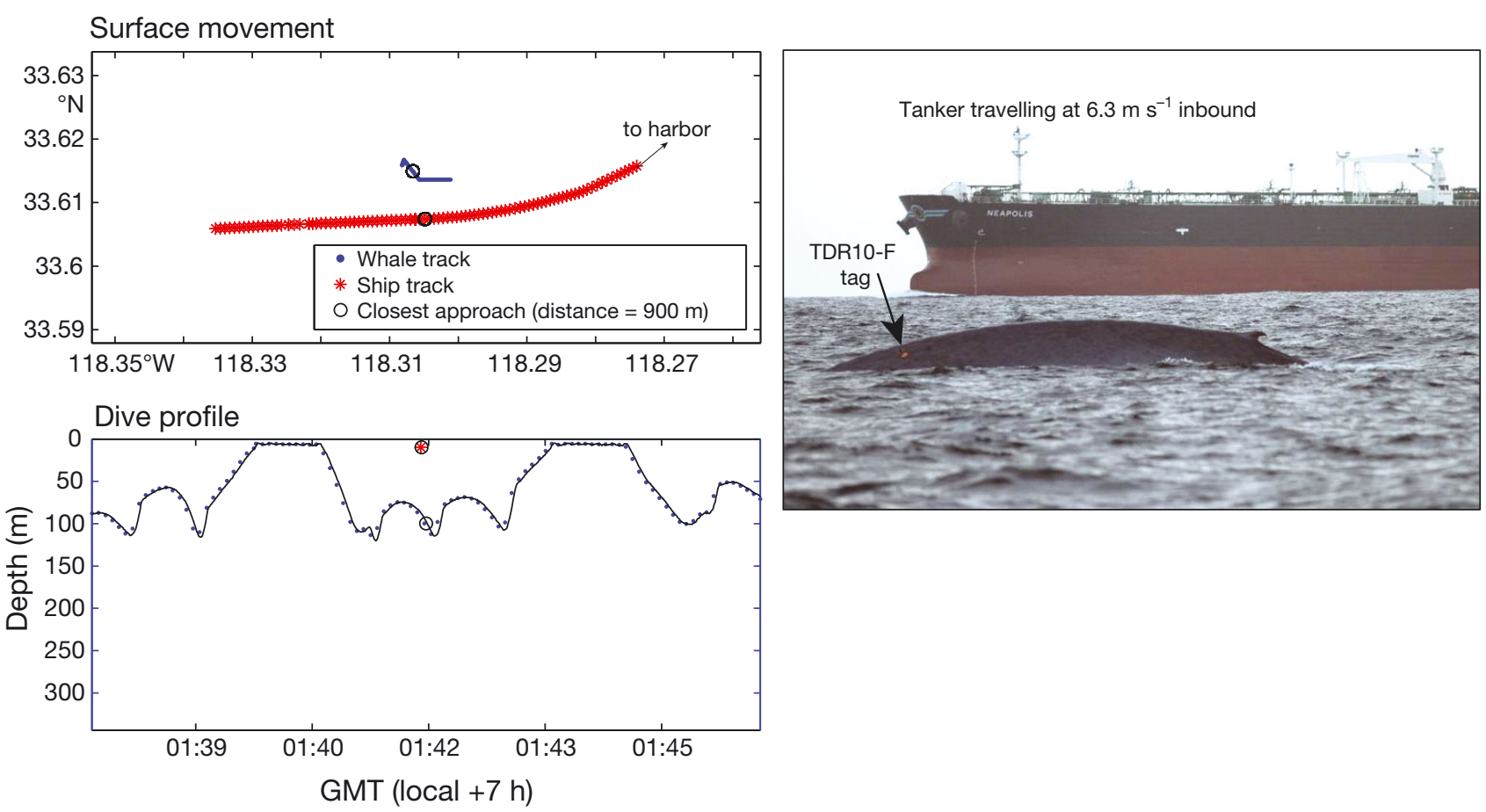

Fig. 2. Verification of methodology combining TDR10-F tag GPS positions of the whales with ship positions from AIS (automatic identification system) data to calculate CPA (closest point of approach). To calculate distance between the ship and whale at CPA, the whale and ship positions closest in time were identified; then, the horizontal distance between the whale and ship was calculated based on these positions. Top left panel: bird's-eye view of the movement of the ship and the whale, including the interpolated track of blue whale (Whale 1) with TDR10-F GPS tag points (blue dots) and the ship track from AIS data stream (red stars). Lower panel: dive profile of the whale, with the red star indicating CPA identified from combining TDR10-F and AIS data. The locations of the ship and the whale at the closest distance are shown as black circles. The right panel shows a photograph just prior to the close approach shown in the left panels $\left(1 \mathrm{knot}=0.514 \mathrm{~m} \mathrm{~s}^{-1}\right)$; the tag is visible on the back of the whale 
making some avoidance response. However, for the purposes of this analysis, we examined possible responses up to $3.6 \mathrm{~km}$ from ships given the small sample size of tagged whales near ships and uncertainty as to whether and what whale responses might be at any distance.

Analysis of tag data provided the following whale behavioral information based on methodology from Goldbogen et al. (2006, 2011): (1) surface duration between deep dives and number of breaths; (2) descent time, angle, and speed; (3) bottom time, number of lunges, and maximum dive depth; and (4) ascent time, angle, and speed. These behavioral variables were collected for the entire tag deployment for each whale using custom-built functions in MATLAB (Mathworks, Version 2012b). This allowed for comparisons between normal diving behavior and dive behaviors during close ship passages.

Whale lateral movements during ship passages were evaluated for evidence of horizontal avoidance at the surface. Using whale positional data (either from the TDR10-F tag or small boat observations), the distance of the whale's surface positions, both before and after CPA, to the ship position at CPA was measured. The heading of the whale from its CPA position to positions after CPA were also calculated. These measurements allowed us to evaluate if a whale moved away from the ship. If so, we would expect the whale distance from the ship's position at CPA to increase after CPA, and the whale heading to remain fairly constant. On the other hand, if the whale's distance from the ship did not increase after CPA and its heading changed, it would indicate the whale did not exhibit directed movement away from the passing ship.

\section{RESULTS}

A total of 20 ship passages (within $3.6 \mathrm{~km}$ of a foraging whale) were analyzed and involved 9 individual blue whales with bio-logging tags attached (Table 1). The ship passages occurred in the commercial shipping lanes that service POLA in southern California (Fig. 1): 3 ship passages occurred just north of Santa Cruz Island in the inbound shipping lane, 5 occurred off the coast of Port

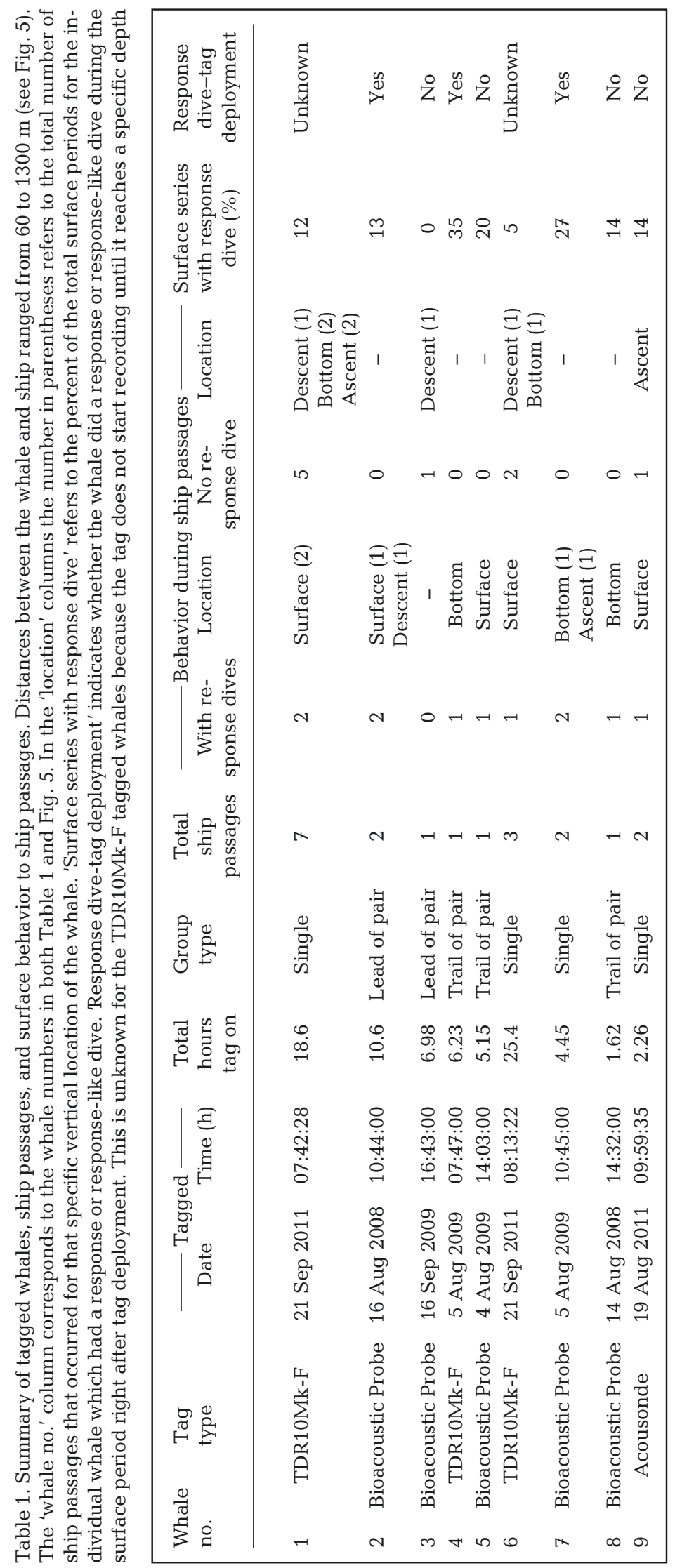


Hueneme in the outbound lane, and the remainder occurred at the entrance to the ports of Los Angeles and Long Beach. The ship-whale encounters involved 6 ship types (bulk carriers, container ship, passenger, roll-on roll-off car carrier [RO-RO], tanker, and vehicle carriers), ship speeds ranging from 5.3 to $15.5 \mathrm{~m} \mathrm{~s}^{-1}$ (10 to 30 knots), different positions of the whales in the water column at CPA (surface, descent, bottom, and ascent), and closest distances of the passages ranging from 60 to $3600 \mathrm{~m}$, including 11 that were considered close approaches (Tables 1 \& 2). All these factors may influence how whales react to approaching ships; therefore, we provide general descriptions of both the lateral movements and dive behaviors of the whales during the ship passages to provide initial insight on blue whale behavioral reactions to close encounters with large commercial ships and their potential vulnerability to ship strikes.

\section{Whale lateral movement during close ship passage}

Lateral movement of whales during ship passages showed little to no evidence of avoidance or movement away from the passing ship (Fig. 3). Four of the 6 encounters that we could analyze for changes in lateral movement resulted in whales actually moving closer to the ship track after CPA (Fig. 3a,c,d,f,h). For these encounters, the whales exhibited a large change in heading $\left(>50^{\circ}\right)$, suggesting that the movement was not in any particular direction or in a direction away from the passing ship (Fig. 3b). This was observed for whales at the surface, at the bottom, and on ascent during CPA of the oncoming ship.

For those whales that showed evidence of movement to a position further from the track of the ship, the difference in distance was small $(<100 \mathrm{~m})$ (Fig. $3 a, c, g$ ), and these 2 whales actually crossed the path of the ship, resurfacing on the other side of the ship track (Fig. 3c,g). The headings to the next position changed by $>50^{\circ}$, suggesting the limited lateral movement was not directed away from the ship (Fig. 3b).

\section{Characteristics of a response dive}

During a $24 \mathrm{~h}$ deployment of a TDR10-F tag on a blue whale, a tanker leaving POLA and traveling at a speed of $5.7 \mathrm{~m} \mathrm{~s}^{-1}(11 \mathrm{knots})$ came within $100 \mathrm{~m}$ of the tagged whale at the surface. In this event, the whale responded by diving below the ship, resurfacing

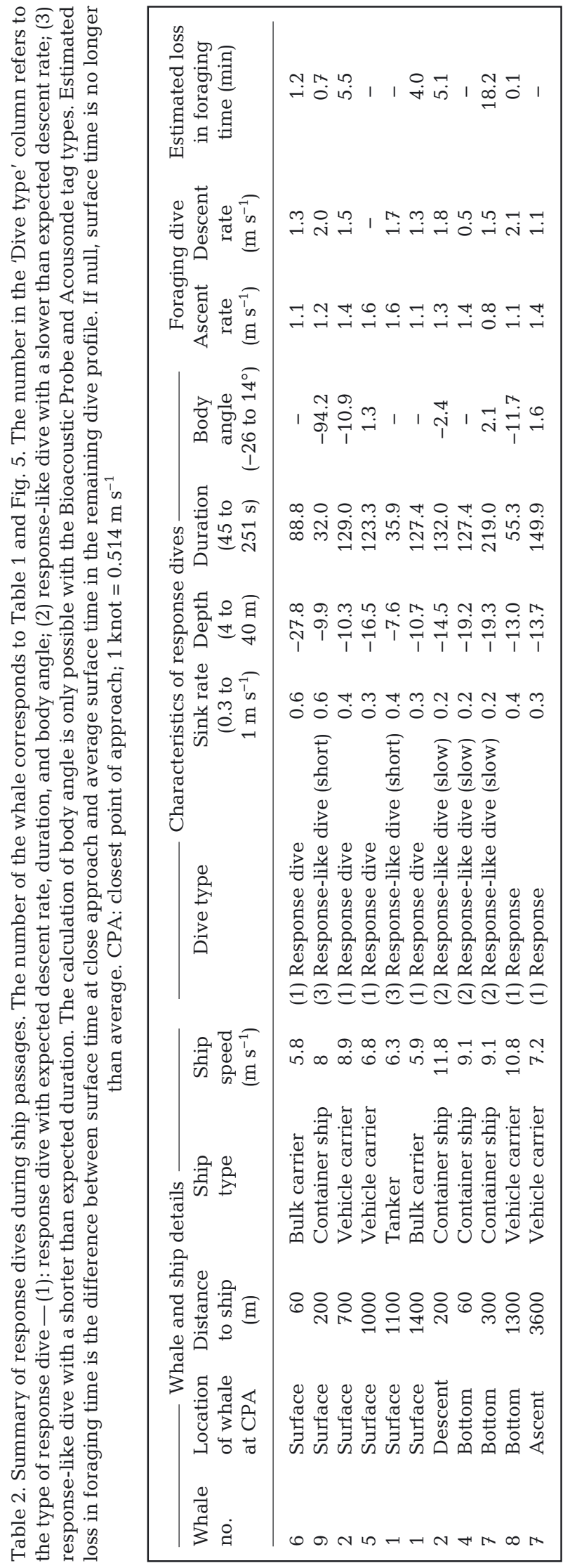



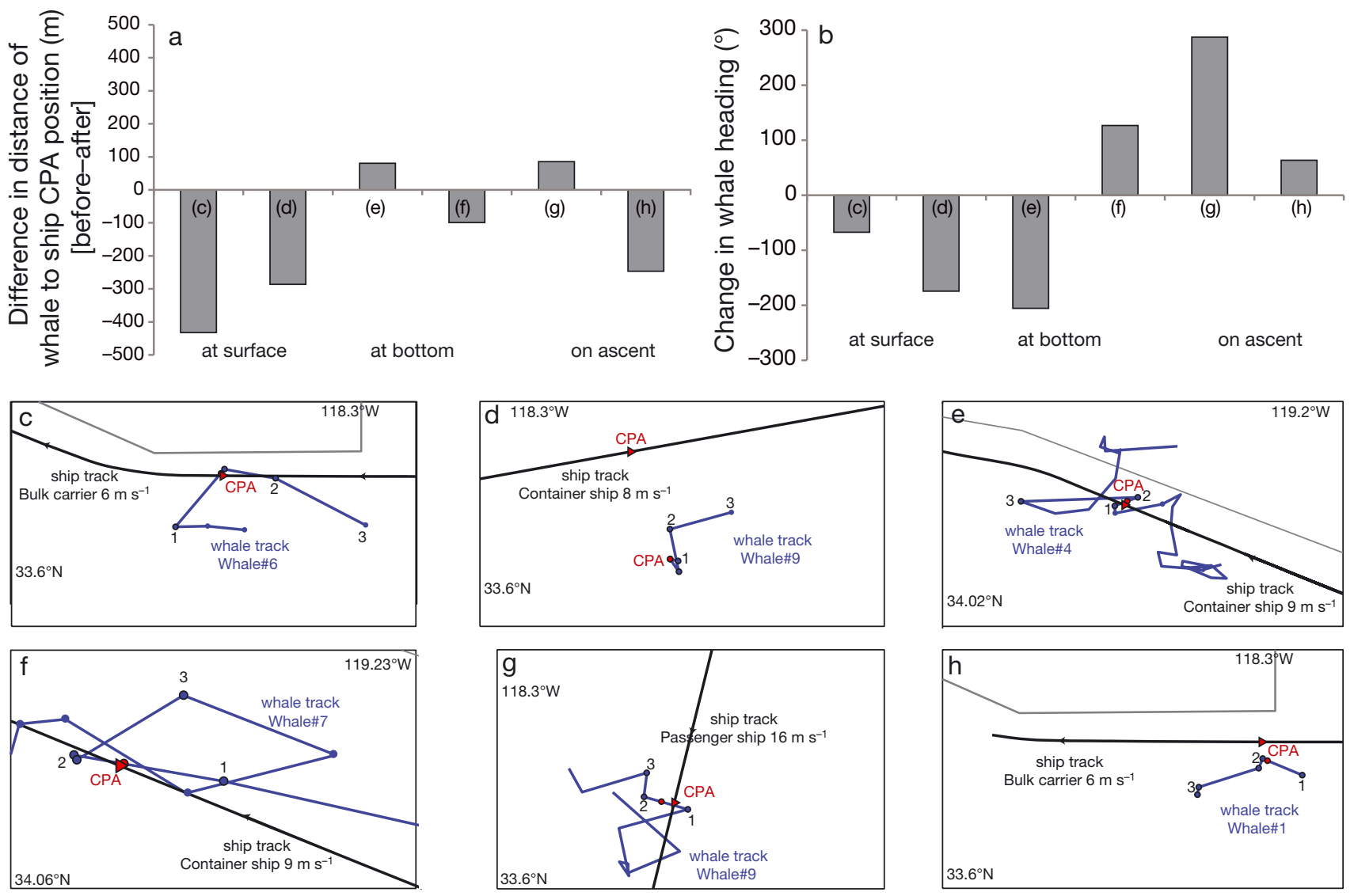

Fig. 3. Summary of horizontal surface movements of whales during ship passages that occurred at distances $<300 \mathrm{~m}$. (a) Difference in distance of the whale to the ship's closest point of approach (CPA) position; negative values indicate the whale moved closer to the ship's CPA position after CPA, and positive values indicate the whale moved further from the ship's CPA position. (b) Change in the heading of the whales before and after CPA. Headings were calculated as the direction (in degrees) from the CPA surface position to the position of the next surface period. The differences between headings were calculated. Values close to zero indicate little change in heading or, possibly, directed movement away from the path of a ship. Positive and negative values indicate the headings were not similar and, therefore, the whale was not traveling in a particular direction. The designations 'at surface', 'at bottom', and 'on ascent' indicate where the whales were during the CPA; the letters on the bars correspond to the lower panels $(\mathrm{c}-\mathrm{h})$ showing the surface movements of whales. $(\mathrm{c}-\mathrm{h})$ Details of whale movement at the time of CPA (indicated by red dot for whale positions and red triangle for ship positions). Data points indicate the order of surface periods - 1: before $\mathrm{CPA}_{;}$red: $\mathrm{CPA}_{i} 2$ : after $\mathrm{CPA}_{i} 3: 2$ surface periods after $\mathrm{CPA}$. In $(\mathrm{c}, \mathrm{e}, \mathrm{h})$ the light gray lines are the borders of the shipping lanes; in $(d, f, g)$ the shipping lanes are outside the resolution of the graphic. $1 \mathrm{knot}=0.514 \mathrm{~m} \mathrm{~s}^{-1}$

1 min after the ship passed, and then made a normal foraging dive about $1 \mathrm{~min}$ after resurfacing behind the ship (see the Supplement at www.int-res.com/ articles/suppl/n027p219_supp/). The whale's reaction began at a distance of $250 \mathrm{~m}$, and the whale descended at a rate of $0.6 \mathrm{~m} \mathrm{~s}^{-1}$ to a depth of $30 \mathrm{~m}$ as the tanker approached the whale's position. This dive type was categorized as a 'response dive'. Additional whale dive data were examined to determine if this type of dive was present in other whale dive profiles and under what circumstances.

We found that response dives were common directly after successful suction-cup tag deployment from a $5 \mathrm{~m}$ rigid-hull inflatable boat and used these dives to define the characteristics of response dives.
Descent rate, duration, depth, and body angle (Fig. 4a) were measured because these characteristics are relevant for evaluating the effectiveness of response dives. We analyzed dive profiles directly after tag attachment for 33 tag deployments to quantify these characteristics. For these same whales, we also measured the characteristics of normal foraging dives. Descent rates were calculated as change in depth over time from the surface to the bottom of the dive. Body angle was derived from the 2-axis accelerometer (Goldbogen et al. 2006), but this was not possible from the TDR10-F tag data.

Duration of response dives after tag attachment ranged from 45 to $251 \mathrm{~s}(\mu=115.5 \pm 69.8)$ and descent rates averaged $0.6 \mathrm{~m} \mathrm{~s}^{-1}\left(0.3\right.$ to $\left.1.0 \mathrm{~m} \mathrm{~s}^{-1}\right)$ at body 

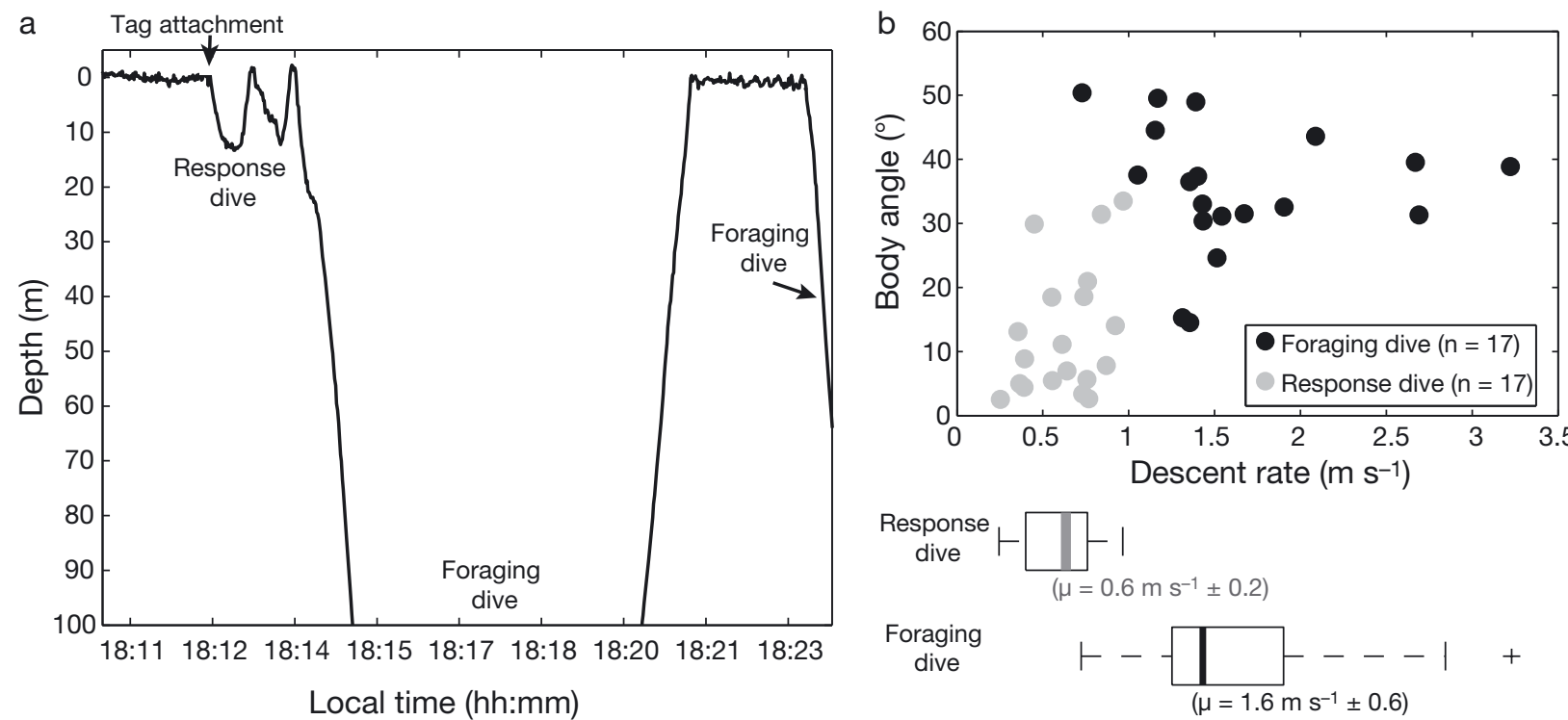

Fig. 4. Blue whale response to suction-cup tag deployments. (a) Example of a whale response dive during successful tag attachment. The response dive is followed by deep foraging dives (bottom of dive profile is not shown). (b) Characteristics (body angle, descent rate) of response dives compared to a foraging dive. Response dives have a significantly slower descent rate and lower body angles. Box plots along the $x$-axis show average descent rates for all response dives compared to foraging dives; a statistically significant difference is found between the dive types. For each box, the central mark is the median, the edges of the box are the 25th and 75th percentiles, the whiskers extend to the most extreme data points not considered outliers, and outlier is plotted individually as a plus sign. The mean value $(\mu)$ is shown for each dive type

angles between 5 and $20^{\circ}$ (Fig. 4b). This was considerably less than typical deep foraging dives $\left(1.6 \mathrm{~m} \mathrm{~s}^{-1}\right.$ descent rate at a 20 to $40^{\circ}$ body angle (Fig. 4 b). These dive parameters provided a basis for identifying any observed whale surface responses during the passage of large ships. The entire dive profile of each whale possibly affected by passing ships was examined for the presence of response dives. This provided a context for assessing how common response dives were in an individual dive profile (Table 1). A response dive during a surface period was confirmed if the duration, descent rate, and body angle fell within the ranges measured from the response dive after tag deployment. If some but not all of the characteristics fell within the ranges, the dive was labeled a 'response-like' dive. If no characteristics matched, the dive was labeled a 'no surface response'.

\section{Ship passages when whales were at the surface at CPA}

For the 6 observed approaches whose CPA occurred when whales were at the surface after a foraging dive (Fig. 5a, Table 2), all whales exhibited a response dive similar to those seen after tag deployments (Fig. 5a). One of the response dives was slightly shorter than typical response dives (Fig. 5a,
Panel 2, Whale \#9), but the response-like dive was within the expected depth, body angle, and descent rate limits.

\section{Ship passages when whales were on descent of a foraging dive at CPA}

Of the 4 whales descending on a foraging dive at CPA only 1 showed evidence of a response dive

Fig. 5. Dive records of whales during ship passages. The rows of plots are organized by the location of the whale at the closest point of approach (CPA): (a) at the surface, (b) on descent, (c) at the bottom of a foraging dive, and (d) on ascent. Each panel in the rows represents a different ship-whale encounter, ordered from closest distance to furthest. The red dots in each panel indicate when the closest distance between the whale and ship occurred. Information on the ship (type, speed, and distance) is provided in the heading of each panel. The whale number at the bottom of each panel corresponds to Tables $1 \& 2$ and Fig. 3. An arrow indicates an observed response or response-like dive. Arrow labeled (1): dive with expected descent rate, duration, and body angle; (2) slower than expected descent rate; (3) shorter than expected duration. If no response dive was observed, the panel is labeled 'no surface response'. Asterisks next to either the descent or ascent of a dive profile indicate a change in rate that is faster $\left({ }^{*}\right)$ or slower $\left({ }^{* *}\right)$ than 1 standard deviation from the mean of all rates in the dive record. Time is local time. $1 \mathrm{knot}=0.514 \mathrm{~m} \mathrm{~s}^{-1}$ 

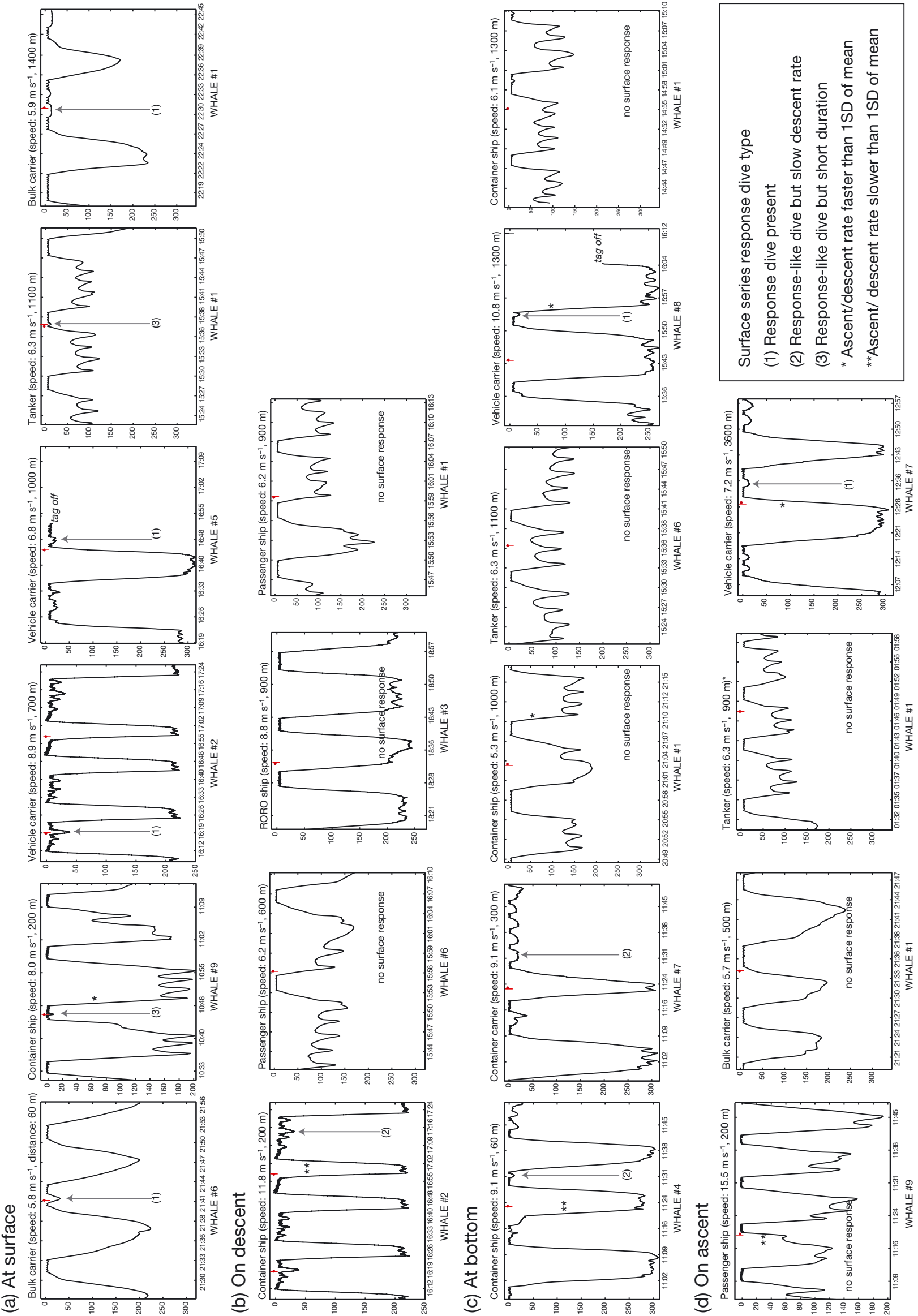

(u) प1də0

(u) प7d də0

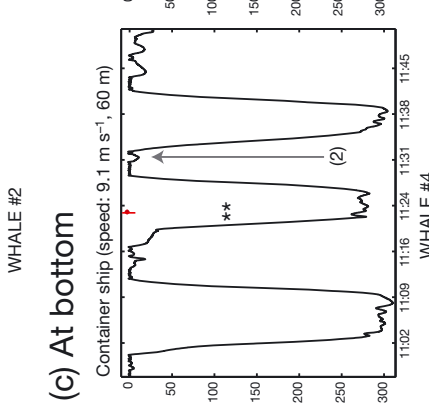

(u) प7də0
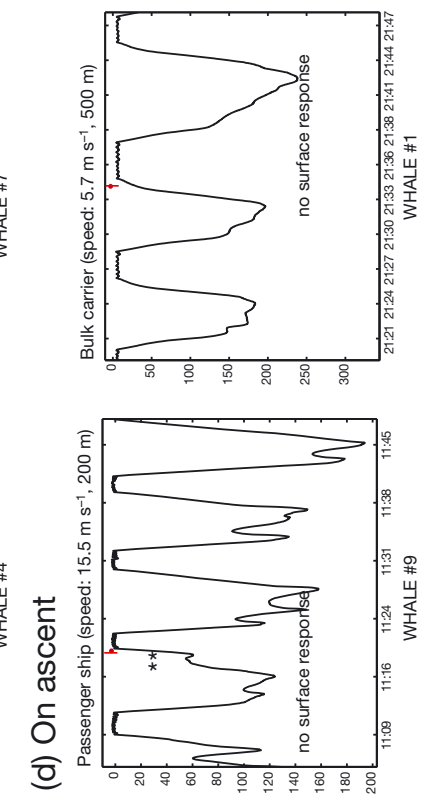

(u) पұdə0 
(Fig. 5b), specifically a series of response dives at the surface period after CPA (Fig. 5b, Panel 1, Whale \#2). In the latter case, a container ship traveling at full speed (11.8 $\mathrm{m} \mathrm{s}^{-1}$ [23 knots]) came within $200 \mathrm{~m}$ of the whale and the acoustic record contained distinct ship noise throughout the bottom portion of the dive. The other 3 whales whose CPA occurred while on descent showed no evidence of a response dive at the surface before or after the CPA. In these cases, ship distances were greater (600 and $900 \mathrm{~m})$ and ships were traveling at slower speeds (Fig. 5b, Panels 2-4; Whales \#6, \#3, \#1).

\section{Ship passages when whales were at the bottom of a foraging dive at CPA}

Six whales were at the bottom of foraging dives when the ship passed overhead (Fig. 5c). Three of the 6 whales exhibited response dives or responselike dives at the surface after the ship passed and in 2 of those cases whales dove at a slower rate $\left(0.2 \mathrm{~m} \mathrm{~s}^{-1}\right)$ than typical response dives (Fig. 5c, Panels 1 \& 2; Whales \#4 and \#7). These 2 whales (Whales 4 \& 7) had the highest proportion response diving during surface periods (35 and $27 \%$; Table 1), making it less clear if these dives were related to the passage of ships. However, the descent rate for Whale 4 (Fig. 5c, Panel 1; Whale \#4) was atypical compared to all other dives in this whale's profile. Whale 8 also exhibited a response dive at the surface after the ship passage (Fig. 5c, Panel 5; Whale \#8) and had a lower proportion of surfaces with response dives $(14 \%)$, suggesting it may be more likely that it was responding to the ship's passage. The ship in that approach was also traveling faster (10.8 $\mathrm{m} \mathrm{s}^{-1}$ [21 knots]) than those in other cases involving whales that were at the bottom of their dive when ships passed (Fig. 5c).

\section{Ship passages when whales were on ascent from a foraging dive at CPA}

For whales that were on ascent at CPA, only 1 of 4 (Whale 7) exhibited a response-like dive to an oncoming ship (Fig. 5d, Panel 4; Whale \#7). Because its response dive had a slower than expected descent rate, this whale had a high percentage of response dives in its profile, and the ship in this case was $3.6 \mathrm{~km}$ away at CPA, the observed response-like dive may not be related to the ship passage.

\section{Changes in ascent and descent rates of foraging dives}

In addition to the presence of response dives as evidence for a behavioral response to the ship passage, we examined ascent and descent rates during deep foraging dives before and after CPA by comparing them to all other dives in the individual whale's dive profile. Seven of the 20 ship-whale encounters showed a change in ascent or descent rates that was at least 1 standard deviation different from the mean of all other ascent and descent rates in the individual's dive profile (Fig. 5). These changes in ascent and descent rates were observed for all whale locations at CPA (surface, bottom, ascent, and descent). During 3 ship passages, descent rates were faster than expected on the foraging dive after CPA (Fig. 5a, Panel 2, Whale \#9; Fig. 5c, Panels 3 \& 5, Whales \#1 and \#8). In 2 of the 20 ship passages, whale descent rates were slower than expected on the foraging dive after CPA (Fig. 5b, Panel 1, Whale \#2; Fig. 5c, Panel 1 , Whale \#4). The ascent rate was faster during 1 encounter (Fig. 5d, Panel 4; Whale \#7) and slower for another ship-whale encounter (Fig. 5d, Panel 1; Whale \#9). The differences in ascent and descent responses may relate to the distance or the speed of the ship at CPA. Additional ship-whale encounters are needed to understand the relationship between these observed changes in behavior and passing ships (e.g. ship speed, ship type).

\section{Ship-whale collision model}

Observed response dive behavior were considered relative to different ship speeds and whale reaction distances to estimate the time needed for a whale to successfully perform a response dive and avoid an oncoming ship. The following equation was used:

$$
W D_{i, j, k}=D R_{i} \times \frac{R D_{j}}{S S P D_{k}}
$$

where $W D_{i, j, k}$ is the depth of the whale for a given descent rate $(D R)$, reaction distance $(R D)$, and ship speed $(S S P D)$. Only whale reactions at the surface were considered in this equation. Input parameters include: whale descent rates between 0.6 and $1.6 \mathrm{~m}$ $\mathrm{s}^{-1}$ and whale reaction distances from 50 to $500 \mathrm{~m}$. Modeled ship speeds ranged from 5.2 to $12.9 \mathrm{~m} \mathrm{~s}^{-1}$ (10 to 25 knots). The model assumed a ship draft of $8 \mathrm{~m}$ and a zone of hydrodynamic risk beneath the ship's hull equal to 2-times the draft (Silber et al. 2010), in this case $16 \mathrm{~m}$. 
a) Response dive decent rate $\left(0.6 \mathrm{~m} \mathrm{~s}^{-1}\right)$

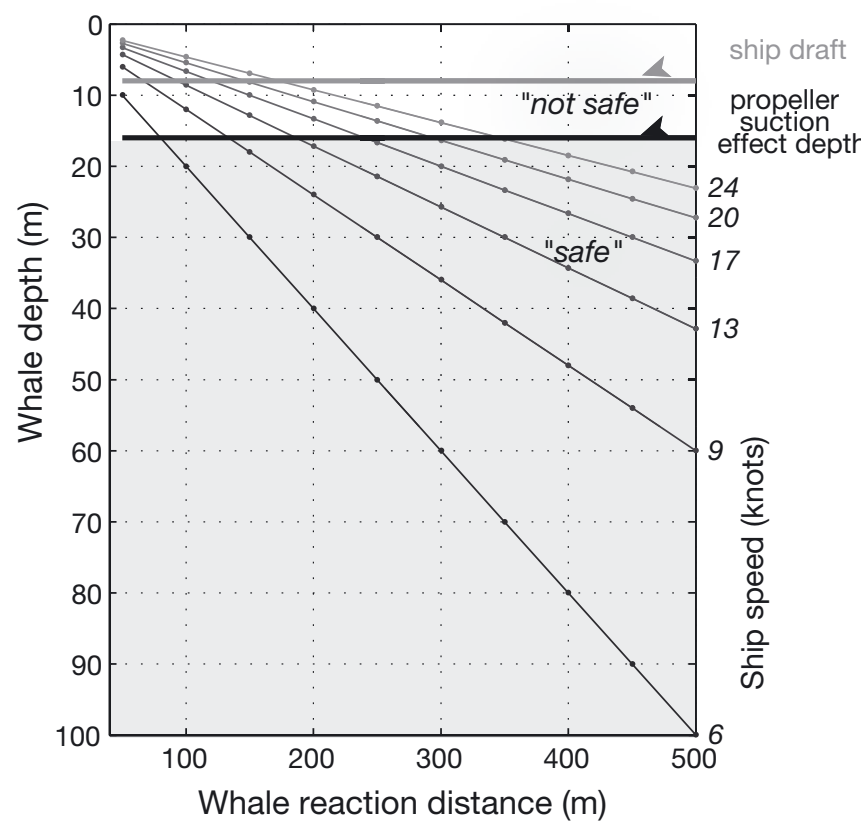

b) Foraging dive descent rate $\left(1.6 \mathrm{~m} \mathrm{~s}^{-1}\right)$

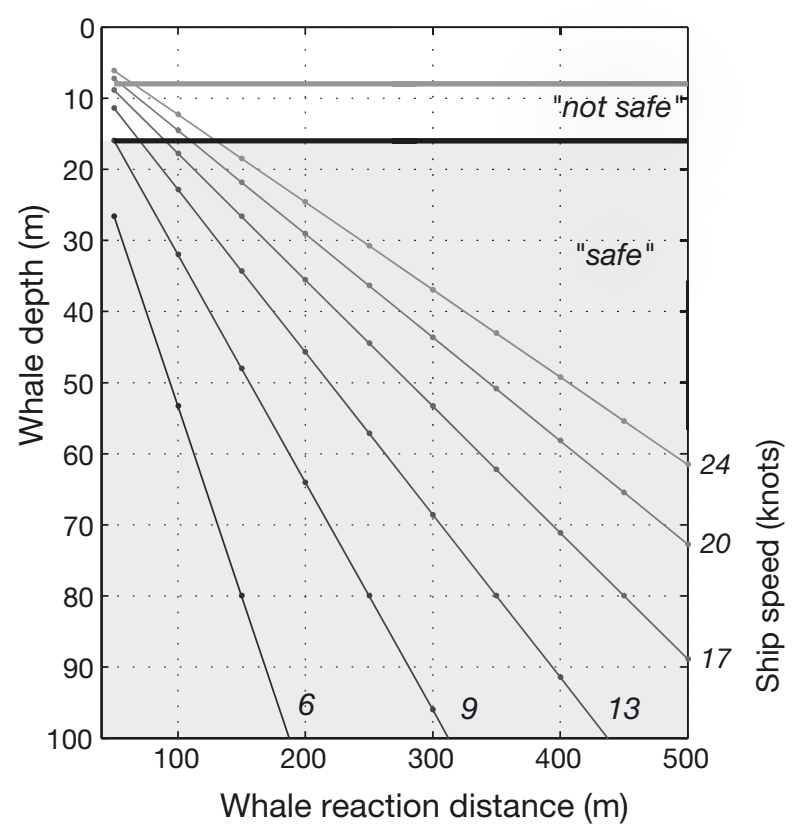

c) Summary

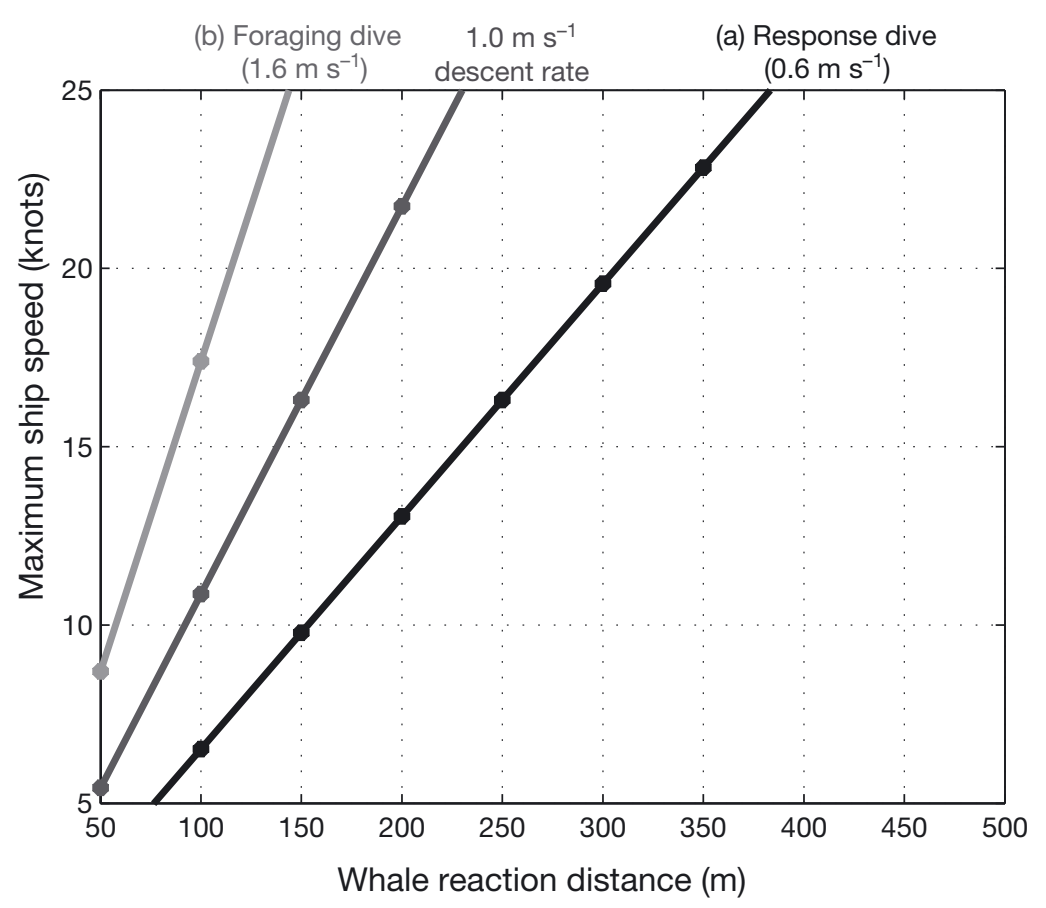

Fig. 6. Modeled depth of whales considered safe from collisions based on reaction distances and ship speeds for descent rate of the (a) response dive and (b) foraging dive. Curves represent different modeled ship speeds (in knots), shown on right vertical axis. (c) Modeled distances at which whales would need to react to 'avoid' collision with the ship as a function of the different descent rates shown in (a) and (b) and for $1.0 \mathrm{~m} \mathrm{~s}^{-1} .1 \mathrm{knot}=0.514 \mathrm{~m} \mathrm{~s}^{-1}$
The results of the simulations using the parameters of the response dive, with different ship speeds and whale reaction distances, showed that a response dive could result in a collision when whale reaction distances are short and ship speeds are fast (Fig. 6a). Based on this model, in the observed case where a whale at the surface initiated a response at a distance of $250 \mathrm{~m}$ from the approaching ship and dove at $0.6 \mathrm{~m}$ $\mathrm{s}^{-1}$ (Fig. 5a, Panel 1; Whale \#6), the whale would not have been able to avoid the hull and hydrodynamic forces of a ship if the ship was traveling at $7.7 \mathrm{~m} \mathrm{~s}^{-1}$ (15 knots) or greater (Fig. 6). If the tanker was travel- 
ing at its normal operating speed $\left(8.8 \mathrm{~m} \mathrm{~s}^{-1}\right.$ [17 knots]), the whale would have had to initiate its dive $275 \mathrm{~m}$ or more before the ship to avoid a collision.

In general, a ship traveling at $6.7 \mathrm{~m} \mathrm{~s}^{-1}$ (13 knots) would require a whale to react with a response dive at a distance of at least $200 \mathrm{~m}$ to avoid collision. For ships traveling at $10.3 \mathrm{~m} \mathrm{~s}^{-1}$ (20 knots), whales would need to begin their response dive at a distance of at least $300 \mathrm{~m}$. At the faster descent rate of foraging dives, the risk of collision is reduced (Fig. 6b). If we assume the reaction distance of a whale is $250 \mathrm{~m}$, then the maximum speed in order for a response dive to be effective is $8.8 \mathrm{~m} \mathrm{~s}^{-1}$ (17 knots) (Fig. 6c).

\section{Additional behavioral effects of close ship passage}

In addition to the limitations of the response dives as an avoidance mechanism, the presence of a response dive during a surface period increases the total surface time, directly reducing the amount of time whales spend foraging. For example, the passage of a container ship when Whale 2 was at the surface resulted in an additional $5.5 \mathrm{~min}$ spent at the surface, when compared to the average surface time from the entire dive record. For this whale, the average frequency of lunges per dive was 0.77 lunges min $^{-1}$ (3 lunges dive ${ }^{-1} ; 3.9$ min bottom time). Increasing the time spent at the surface by 5.5 min may result in as many as 4 fewer lunges (Table 2). Given that there is a tradeoff between the response dive and lost foraging time, whales may be choosing when to react based on the perception of the threat. Whales foraging in the shipping lanes only showed consistent reactions when at the surface during CPA and for faster moving ships.

\section{DISCUSSION}

Our study region was identified as an area of high ship-strike risk (Berman-Kowalewski et al. 2010, Redfern et al. 2013), and our analysis of blue whale behavior showed that whales do not appear to avoid areas of heavy ship traffic (e.g. commercial shipping lanes), nor, according to the results of our study, do they move laterally away from oncoming ships (Fig. 3). Our study did find evidence that blue whales are capable of reacting to avoid approaching ships (within $3.6 \mathrm{~km}$ ) using a response dive when at the surface. Response dives were observed in $55 \%$ of the ship passages, and were most common when whales were at the surface and passing ships were at their closest distance. However, the response of blue whales to oncoming ships was of limited effectiveness in avoiding collision, inconsistent across situations (e.g. ship types and whale locations), and likely to be incapable of adjusting to varying ship speeds (Fig. 6). Although recent evidence suggests shipstrikes are not an immediate threat to the survival of this population of blue whales (Monnahan et al. 2014), the levels of mortality from ship-strikes are still above legal limits set by the USA. The limited effectiveness of response dives and lack of evidence for lateral movement in reaction to approaching ships shows that blue whales are vulnerable to collisions with ships, especially in regions of high ship traffic. Mitigating the risk of ship strikes remains a legal priority in these regions.

Slower ship speeds have been identified as a mitigation strategy for reducing ship-whale collisions. The primary evidence for this benefit has been the reduced lethality of collisions when they occur with slower ships (Laist et al. 2001, Conn \& Silber 2013, Laist et al. 2014). Unfortunately, most ship-whale collisions are not documented at the time of occurrence. Thus, the ship types and speeds most frequently causing collisions remain unknown. Most ship-strike deaths are primarily documented in reports of stranded whales with blunt force trauma or other injuries indicative of ship-strike. However, these underrepresent the true scope of the issue, since only a small portion of whale mortality results in carcasses washing ashore (Williams et al. 2011). The lack of information on the factors contributing to ship-strikes makes it difficult to determine how ship speed alters the incidence and lethality of shipstrikes. Only if whales respond differently to slower ships or make use of the added time to respond would slower ship speeds reduce the incidence of ship-strikes and not just their lethality. Prior to this research, data on whale responses to ships in collision situations have been limited.

The response dives we describe would be more effective in avoiding slower-moving ships than fast ones, assuming whale responses occur at the same distance to the oncoming ship. For a response dive to be effective when ships are traveling at $8.8 \mathrm{~m} \mathrm{~s}^{-1}$ (17 knots) (Fig. 6c), whales would need to initiate a response dive with a descent rate of $0.6 \mathrm{~m}$ about 250 $\mathrm{m}$ in front of an oncoming ship. We evaluated how whale reaction distance, whale descent rates, and ship speeds interact to affect the likelihood of ship-whale collisions. Our methodology assessed collision risk based on measured parameters of a 
response dive during ship passages (Fig. 6). However, given our limited sample size, it remains unknown how different ship speeds affect the distance at which whales react. If whales react to faster ships at greater distances, then it would somewhat reduce the risk, while if the reverse were true, it would increase the vulnerability to faster-moving ships.

The sound or other signal that caused the whales observed in this study to react to the approaching ships is unknown. Previous research that broadcasted ship sounds to right whales did not elicit a response (Nowacek et al. 2004); however, the distances tested were greater than the response distance observed in this study. At closer distances in this study, ship noise could sometimes be detected on the acoustic tags. There is a possibility that the reaction to the oncoming ship may be a visual response. Blue whales are known to use visual cues to optimize prey intake by diving under the prey patch and directing foraging lunges on back-lit prey patches (Goldbogen et al. 2013).

The ship approaches documented in this study revealed distinctive short-term shallow dive avoidance responses that did not prevent the whale from quickly resuming normal foraging dives. This response was comparable to dive behavior measured directly after tag deployments, and possibly represents a general reaction to perceived threats at the surface. In contrast to response dives, foraging dives after surface recovery intervals were characterized by faster descent rates at steeper body angles (Goldbogen et al. 2011), suggesting that whales at the surface may not typically use high-energy rapid descent dives to avoid surface threats.

The presence of response dives results in longer surface periods, which may increase whale vulnerability to collisions with other ships traveling in the same lane and after a previous ship passage, particularly in regions with high levels of ship traffic. Furthermore, the lack of lateral avoidance keeps whales within the shipping lanes during this extended surface period. Ship behavior around ports frequently results in stacking up of ships depending on schedules at the port (McKenna et al. 2009), possibly resulting in certain regions and time periods of increased risk of ship strike.

Differences in ship size, ship speed, bow design, or whale activities at the time of ship encounters likely influence whale response behavior (Ellison et al. 2012). If behavior during ship encounters varies by species, it may explain the apparent differences in collision rates for different species (Douglas et al.
2008). The approach of this study offers a method to assess such variables and determine what ship speeds may reduce, not just the lethality of collisions, but also how speed may alter the incidence of ship strikes. The integration of high-resolution data from bio-logging tags with ship AIS data provides the necessary information to evaluate whale behavior in different scenarios, and we encourage similar studies to expand sample size.

Acknowledgements. Tag data were collected under NOAANMFS Permit 540-1811 issued to J. Calambokidis. The authors gratefully acknowledge the efforts of all involved in collecting these data, especially: S. Katz, K. Stingle, S. Kerosky, A. Friedlaender, B. Southall, E. Falcone, G. Schorr, C. Garsha and numerous field volunteers. We thank Steve Katz of the Channel Islands National Marine Sanctuary for continued support of the project, securing time onboard the RV 'Shearwater', his assistance with field logistics, and his insight on data analysis. The Channel Islands National Marine Sanctuary provided assistance in field operations, and T. Shinn, M. Davis, and C. Lara are thanked for their help. This work was supported by ONR, Award Number N000140811221 to E. Oleson and J. Hildebrand. Additional funds were provided by a NMFS Marine Mammal Conservation Division, National Academy of Science, postdoctoral fellowship awarded to the senior author and Channel Islands National Marine Sanctuary.

\section{LITERATURE CITED}

Barlow J (1995) The abundance of cetaceans in California waters. Part 1: ship surveys in summer and fall of 1991. Fish Bull 93:1-14

Berman-Kowalewski M, Gulland FMD, Wilkin S, Calambokidis J and others (2010) Association between blue whale (Balaenoptera musculus) mortality and ship strikes along the California coast. Aquat Mamm 36:59-66

> Calambokidis J, Barlow J (2004) Abundance of blue and humpback whales in the eastern North Pacific estimated by capture-recapture methods. Mar Mamm Sci 20:63-85

Calambokidis J, Steiger GH, Cubbage JC, Balcomb KC and others (1990) Sightings and movements of blue whales off central California 1986-1988 from photo-identification of individuals. Rep Int Whal Comm 12:343-348

Calambokidis J, Steiger GH, Rasmussen K, Urbán J and others (2000) Migratory destinations of humpback whales that feed off California, Oregon and Washington. Mar Ecol Prog Ser 192:295-304

Calambokidis J, Schorr G, Steiger G, Francis J and others (2007) Insights into the underwater diving, feeding, and calling behavior of blue whales from a suction-cupattached video-imaging tag (Crittercam). Mar Technol Soc J 41:19-29

Calambokidis J, Barlow J, Ford JKB, Chandler TE, Douglas AB (2009) Insights into the population structure of blue whales in the eastern North Pacific from recent sightings and photographic identification. Mar Mamm Sci 25: 816-832

Campbell-Malone R, Barco S (2008) Gross and histologic evidence of sharp and blunt trauma in North Atlantic 
right whales (Eubalaena glacialis) killed by vessels. J Zoo Wildl Med 39:37-55

Carretta JV, Oleson EO, Weller DW (2012) US Pacific marine mammal stock assessments. US Department of Commerce, NOAA Tech Memo, NMFS-SWFSC-504:1-378

CINMS (Channel Islands National Marine Sanctuary) (2009) Final management plan: final environmental impact statement. US Department of Commerce, Washington, DC. http://sanctuaries.noaa.gov/management/mpr/cinmsmp.pdf (accessed 15 Mar 2010)

Clapham PJ, Young SB, Brownell RL (1999) Baleen whales: conservation issues and the status of the most endangered populations. Mammal Rev 29:37-62

Conn P, Silber G (2013) Vessel speed restrictions reduce risk of collision-related mortality for North Atlantic right whales. Ecosphere 4:art43

Corbett J, Winebrake J (2007) Sustainable goods movement: enviromental implications of trucks, trains, ships, and planes. Environ Manage November 2007, p 8-12

> Douglas AB, Calambokidis J, Raverty S, Jeffries SJ, Lambourn DM, Norman SA (2008) Incidence of ship strikes of large whales in Washington State. J Mar Biol Assoc UK 88:1-12

Ellison WT, Southall B, Clark C, Frankel A (2012) A new context-based approach to assess marine mammal behavioral responses to anthropogenic sounds. Conserv Biol 26:21-28

> Gende SM, Hendrix AN, Harris KR, Eichenlaub B, Nielsen J, Pyare S (2011) A Bayesian approach for understanding the role of ship speed in whale-ship encounters. Ecol Appl 21:2232-2240

Goldbogen JA, Calambokidis J, Shadwick RE, Oleson EM, McDonald MA, Hildebrand JA (2006) Kinematics of foraging dives and lunge-feeding in fin whales. J Exp Biol 209:1231-1244

> Goldbogen JA, Calambokidis J, Oleson E, Potvin J, Pyenson ND, Schorr G, Shadwick RE (2011) Mechanics, hydrodynamics and energetics of blue whale lunge feeding: efficiency dependence on krill density. J Exp Biol 214:131-146

Goldbogen JA, Calambokidis J, Friedlaender AS, Francis J and others (2013) Underwater acrobatics by the world's largest predator: $360^{\circ}$ rolling manoeuvres by lungefeeding blue whales. Biol Lett 9:20120986

Lagueux KM, Zani MA, Knowlton AR, Kraus SD (2011) Response by vessel operators to protection measures for right whales Eubalaena glacialis in the southeast US calving ground. Endang Species Res 14:69-77

Laist D, Knowlton A, Mead J, Collet A, Podesta M (2001) Collisions between ships and whales. Mar Mamm Sci 17:35-75

Laist DW, Knowlton AR, Pendleton D (2014) Effectiveness of mandatory vessel speed limits for protecting North Atlantic right whales. Endang Species Res 23:133-147

McKenna MF, Soldevilla MS, Oleson E, Wiggins SM, Hildebrand JA (2009) Increased underwater noise levels in the Santa Barbara Channel from commercial ship traffic and the potential impact on blue whales. In: Damiani C, Garcelon D (eds) Proceedings of the 7th California Islands Symposium. Institute for Wildlife Studies, Arcata, CA, p 141-149
McKenna M, Katz S, Condit C, Walbridge S (2012) Response of commercial ships to a voluntary speed reduction measure: Are voluntary strategies adequate for mitigating ship-strike risk? Coast Manage 40:634-650

Miksis-Olds JL, Donaghay PL, Miller JH, Tyack PL, Reynolds JE III (2007) Simulated vessel approaches elicit differential responses from manatees. Mar Mamm Sci 23: $629-649$

Monnahan CC, Branch TA, Punt AE (2014) Do ship strikes threaten the recovery of endangered eastern North Pacific blue whales? Mar Mamm Sci 31:279-297

- Neilson JL, Gabriele CM, Jensen AS, Jackson K, Straley JM (2012) Summary of reported whale-vessel collisions in Alaskan waters. J Mar Biol 2012:1-18

Nowacek D, Johnson M, Tyack P (2004) North Atlantic right whales (Eubalaena glacialis) ignore ships but respond to alerting stimuli. Proc R Soc Lond B Biol Sci 271:227-231

> Redfern JV, McKenna MF, Moore TJ, Calambokidis J and others (2013) Assessing the risk of ships striking large whales in marine spatial planning. Conserv Biol 27: 292-302

Rycyk A (2013) Manatee behavioral response to approaching boats. PhD thesis, Florida State University. http:// diginole.lib.fsu.edu/cgi/viewcontent.cgi? article $=7604 \&$ context=etd

Silber GK, Bettridge S (2012) An assessment of the final rule to implement vessel speed restrictions to reduce the threat of vessel collisions with North Atlantic right whales. US Department of Commerce, Washington, DC

Silber GK, Slutsky J, Bettridge S (2010) Hydrodynamics of a ship/whale collision. J Exp Mar Biol Ecol 391:10-19

Silber GK, Vanderlaan ASM, Tejedor Arceredillo A, Johnson L and others (2012) The role of the International Maritime Organization in reducing vessel threat to whales: process, options, action and effectiveness. Mar Policy 36: 1221-1233

Tetreault BJ (2005) Use of the automatic identification systems (AIS) for maritime domain awareness. In: Proceedings of OCEAN 2005, Washington, DC, Sep 2005. Ocean Proc MTS/IEEE 2:1590-1594

> Van der Hoop JM, Vanderlaan ASM, Taggart CT (2012) Absolute probability estimates of lethal vessel strikes to North Atlantic right whales in Roseway Basin, Scotian Shelf. Ecol Appl 22:2021-2033

> Van der Hoop JM, Moore MJ, Barco SG, Cole TVN and others (2013) Assessment of management to mitigate anthropogenic effects on large whales. Conserv Biol 27:121-133

Vanderlaan ASM, Taggart CT (2007) Vessel collisions with whales: the probability of lethal injury based on vessel speed. Mar Mamm Sci 23:144-156

Wiley DN, Thompson M, Pace RM III, Levenson J (2011) Modeling speed restrictions to mitigate lethal collisions between ships and whales in the Stellwagen Bank National Marine Sanctuary, USA. Biol Conserv 144:2377-2381

Williams R, Gero S, Bejder L, Calambokidis J and others (2011) Underestimating the damage: interpreting cetacean carcass recoveries in the context of the Deepwater Horizon/BP incident. Conserv Lett 4:228-232

Submitted: June 23, 2014; Accepted: December 29, 2014

Proofs received from author(s): April 11, 2015
Editorial responsibility: Clive McMahon, Darwin, NT, Australia 